DOCTRINA

\title{
Interpretaciones de elemento «entrada ilegal» en el tráfico ilícito de migrantes y las ambigüedades del bien jurídico
}

\author{
"Coyotaje»: contradiction in the illegal entry of smuggling of migrants \\ and the ambiguities in the legal interest protected
}

\author{
Tania Alejandra Gajardo Orellana (D) \\ Universidad de los Andes, Chile
}

\begin{abstract}
RESUMEN Este trabajo trata acerca de las interpretaciones del elemento normativo «entrada ilegal» en el medianamente «nuevo» delito de tráfico ilícito de migrantes. Este tipo se incorporó al Código Penal chileno en 2011 tras la suscripción de la Convención de Palermo y sus protocolos. Uno de los problemas que presenta la figura es la descripción de la conducta a través de verbos rectores (promover o facilitar) con referencia a la entrada ilegal. No solo falta definir qué configura semejante entrada, sino que tampoco hay claridad sobre su exigencia, lo que repercute en la clase de delito que se trata, el lugar de comisión e incluso la participación. Por la relevancia y las dificultades de este elemento normativo, se tratan las principales interpretaciones sostenidas tanto en la jurisprudencia como en la doctrina nacional. Las distintas tesis parecen obedecer a la ambigüedad que reina acerca del bien jurídico. Aquí se postula una interpretación amplia de la entrada ilegal, coherente con la disposición legal vigente y consecuente con la tutela del control de flujos migratorios. Se incluye un excurso dedicado al proyecto de Ley de Migraciones actualmente en trámite en el Congreso Nacional, disposiciones a las que en el futuro deberá remitirse quien interprete este elemento normativo. ${ }^{1}$
\end{abstract}

PALABRAS CLAVE Tráfico ilícito de migrantes, entrada ilegal, bien jurídico tutelado.

ABSTRACT This paper deals with normative element «illegal entry» in the «new» crime of smuggling of migrants. This criminal type was incorporated in Chile in 2011, after the signing of the Palermo Convention and its Protocols. One of the problems presented

1. La materia es novedosa en Chile y lleva a interesantes debates, pero se advierte que este trabajo se centra en las interpretaciones de entrada ilegal y sus vínculos con las posturas de bien jurídico en Chile, sin pretensiones de dar soluciones a otros tópicos vinculados al tema. 


\begin{abstract}
by the figure is the description of the behavior through guiding verbs (promoting or facilitating) with reference to illegal entry. Not only do we need to define what constitutes such an entry, but there is also no clarity about its requirement, which affects the type of crime in question, the place of commission and even participation. Due to the relevance and difficulties of this normative element, the main interpretations sustained both in jurisprudence and in national doctrine are discussed. The different theses seem to obey the ambiguity that reigns about the legal interest protected. This paper argues that the broad interpretation of illegal entry is consistent with border control protection. It includes a speech dedicated to the draft Migration Law, currently being processed by the National Congress, a rule to which the interpreter of this normative element should be referred in the future.
\end{abstract}

KEYWORDS Smuggling of Migrants, illegal entrance, legal interest protected.

\title{
Introducción
}

Hasta antes del cierre de fronteras por la pandemia, en Chile se vivían las consecuencias de un aumento explosivo de la migración. En este contexto, es importante mencionar que los motivos para migrar son tan variados como personas migrantes hay en el mundo. La novedad es que, en Chile, el hecho de que el país se haya transformado en receptor de migrantes se transformó en un tema de la mayor relevancia desde diversas aristas, como la social, económica, cultural y jurídica (Sandoval, 2018: 27).

Aquí trataremos solo la esfera jurídica y, dentro de este ámbito, abordaremos más específicamente la respuesta del derecho penal ante la figura conocida usualmente como "coyotaje», que se refiere, en el imaginario social, a quien cobra por facilitar el cruce de fronteras de manera ilegal desde un país a otro (Spener, 2008: 132). Esta figura apareció en Chile en 2011 con la Ley 20.507, que introdujo al Código Penal el tipo de tráfico ilícito de migrantes. Con él, se persigue y castiga a quienes promueven o facilitan, con ánimo de lucro, el ingreso ilegal al país de personas extranjeras. El ánimo parece remitir al cobro y el ingreso parece exigir cruce. Sin embargo, veremos que no hay claridad con respecto a estos elementos y otros.

De todas las dificultades que puede enfrentar el delito, este trabajo se aboca a las distintas interpretaciones del elemento normativo ingreso ilegal, que parece central a la hora de determinar la conducta típica. Las diversas concepciones están, presumiblemente, marcadas por la ambigüedad que reina sobre el bien tutelado por la norma penal.

Hasta ahora, se han visto situaciones de ingresos ilegales al país que exceden las conocidas hipótesis de ingresos fraudulentos o clandestinos, en los que, por ejemplo, se viaja con documentos verdaderos y por pasos habilitados, pero se declaran finalidades falsas al funcionario contralor o se entra con visados verdaderos, pero 
obtenidos con antecedentes falsos, entre otras situaciones. Lo primero será definir qué se entiende por entrada ilegal para, posteriormente, comprender si las hipótesis novedosas están o no dentro del elemento normativo del tipo.

Para establecer el significado de la entrada ilegal se considerará, en primer lugar, el Decreto Ley de Extranjería, sustento administrativo al que se recurre para dotar de contenido a esta referencia. El Decreto era la única regulación en Chile en la que se establecían delitos relacionados con la migración. También, se hará una breve alusión a la Convención de Palermo y a su protocolo contra el tráfico ilícito de migrantes como marco de referencia internacional. En ambos podemos encontrar pautas para definir qué en entrada ilegal, y han jugado un rol relevante en las interpretaciones que se han sostenido en el país acerca de este elemento normativo.

La segunda parte de este estudio abordará las diferentes interpretaciones de la entrada ilegal, cuyo desarrollo ha sido principalmente jurisprudencial. Para ello, se consideran todas las sentencias en juicios orales del país hasta marzo de 2019, en las que se ha discutido alguna postura sobre el ingreso o la entrada ilegal. Estas se sistematizan en dos grandes grupos: uno realiza una interpretación amplia del ingreso o entrada ilegal por la exigencia de cualquier contravención a las normas de ingreso al país y el otro mantiene una interpretación restrictiva al requerir que la entrada del migrante constituya alguno de los delitos de los artículos 68 o 69 del Decreto Ley de Extranjería, es decir, que el ingreso sea clandestino o fraudulento. ${ }^{2}$

Posteriormente, se expondrá la discusión que ha generado este tipo penal en la doctrina nacional, la que se ha centrado en las nociones del bien jurídico tras el tráfico de migrantes. La exposición no solo obedece a la mayor atención dogmática, sino también a las repercusiones que se advierten al relacionar la tesis acerca del bien jurídico con las distintas nociones sobre la entrada ilegal.

Esta relación puede sistematizarse de la siguiente forma, ya que se distinguen tres grandes vertientes: la que sostiene que el bien jurídico es el control de fronteras o sistema migratorio con su consecuente interpretación del ingreso ilegal (Segovia, 2013: 233; Gajardo y Torres, 2011: 236); la que se decanta por la protección de la integridad moral o la dignidad con su respectiva concepción de entrada ilegal (Mardones y Fernández, 2011: 14); y, por último, las que entienden que se protegen los derechos de los ciudadanos extranjeros con sus propias consecuencias interpretativas (Salinero, 2019: 576).

En el intento de resolver algunas de las ambigüedades detectadas, se estudiaron particularmente las dos únicas sentencias de la Corte Suprema de marzo de 2019 que se refieren a este delito, en las que se conocen y fallan dos recursos de nulidad sobre

2. Para revisar distintas interpretaciones en Chile con respecto a la entrada ilegal, sin perjuicio de las que se verán en mayor profundidad, véase Segovia (2013: 233), Gajardo y Torres (2011: 236) y Salinero (2019: 563). 
un mismo caso conocido mediáticamente como Operación desierto. ${ }^{3}$ Destaca la interpretación de la Corte con respecto al bien jurídico afectado, que incide en la precisión de la conducta típica.

En este estudio se plantea como tesis que las distintas interpretaciones del elemento normativo entrada ilegal obedecen mayormente a la ambigüedad del bien jurídico. No hay claridad en Chile, ni en la doctrina comparada relevante para la regulación nacional, acerca de qué es lo que pretende proteger la sanción de este delito. Así, de sostenerse que se tutela un bien jurídico colectivo vinculado al control migratorio, se interpreta de manera amplia el ingreso ilegal. Al contrario, las posturas de bien jurídico individual ligadas a la dignidad, integridad moral o derechos de los migrantes han servido de fundamento para interpretar de manera restrictiva el elemento entrada ilegal.

Finalmente, se agrega un excurso con observaciones al proyecto de Ley de Migración (Boletín 8970-06) que reemplazaría el Decreto Ley de Extranjería de 1975 debido a sus eventuales repercusiones con respecto a la consideración de la entrada ilegal. Se verá que podría continuar el mismo problema al separar de los impedimentos prohibitivos de ingreso, las declaraciones falsas, y dejarlas como impedimentos facultativos.. Para el estudio de la conducta típica y la delimitación del problema vinculado con la definición de la entrada ilegal, se comienza con el contexto que explica la introducción del tipo penal.

\section{Escenario chileno antes de la tipificación del tráfico ilícito de migrantes y su introducción en el Código Penal}

Sanciones administrativas y penales del Decreto Ley de Extranjería. Bases argumentativas para dotar de contenido al elemento normativo entrada ilegal

En el Decreto Ley de Extranjería hay sanciones administrativas y penales relacionadas con el ingreso ilegal al país. Además, este cuerpo legal contempla los requisitos para el ingreso legal a Chile, cuyo incumplimiento podría dar lugar a un ingreso ilegal relevante para la figura penal que aquí interesa.

Para ingresar legalmente al país, se establecen una serie de requisitos dependiendo de la calidad con la que se hará dicho ingreso. ${ }^{4}$ En términos generales, debe realizarse por pasos habilitados, con documentos de identidad válidos y, en los casos en que se exige visación previa, debe haber sido obtenida legalmente y encontrarse vigente.

Las calidades en las que los extranjeros pueden ingresar al país son las de turista, residente y residente oficial. Los residentes no oficiales pueden serlo con las siguien-

3. Asociación ilícita para el tráfico de migrantes desde República Dominicana a Chile, aproximadamente 120 migrantes traficados.

4. Para más información, véase el artículo 2 del Decreto Ley 1094 de 1975. 
tes denominaciones: «sujeto a contrato», «residente estudiante», «residente temporario», $\mathrm{y}$ «residente con asilo político» o «refugiado». Los residentes oficiales son los funcionarios consulares, cuerpos diplomáticos y funcionarios de organismos internacionales acreditados en Chile a quienes se les otorga dicha calidad.

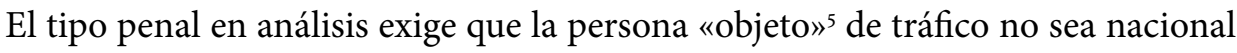
ni residente, por lo que debe tratarse de un extranjero que no tenga ninguna de las calidades de residente indicadas anteriormente. Así, solo queda la posibilidad de que si el ingreso es por paso habilitado, se trate de personas que viajan en calidad de turistas o que buscan obtener el estatus de refugiados.

De los turistas, debe distinguirse entre los que provienen de países a los que Chile no les exige visación consular en el país de origen (regla general) y a los que sí se les exige. ${ }^{6}$ Por su parte, las personas que solicitan la calidad de refugiados incluso pueden pedirla habiendo realizado el ingreso al país por paso no habilitado. En esta materia, lo relevante es el riesgo que corre la persona que solicita dicha calidad.

En este sentido, dependiendo de la calidad en la que viajan las personas, de su país de origen y de su declaración al ingresar a Chile, se puede analizar si su ingreso cumplió o no con las normas de ingreso del Decreto Ley de Extranjería.

Los sujetos que ingresan al país infringiendo las causales de impedimento y prohibiciones de ingreso cometen un delito sancionado en el artículo 69, inciso 3, del mismo Decreto Ley. Otras infracciones que pueden cometer los migrantes una vez dentro del país, relacionadas con exigencias administrativas migratorias, generalmente se sancionan con multas. ${ }^{7}$

Además de señalar los requisitos de ingreso y egreso del país, el Decreto Ley sanciona administrativamente a los transportistas y hoteleros que no registran correctamente y que no presentan documentos de viaje válidos, a sus transportados y pasajeros. ${ }^{8}$ La conducta de la transportista acreedora de sanción administrativa podría verse estrechamente relacionada, e incluso confundirse, con la promoción o facilitación del ingreso ilegal con ánimo de lucro que exige el tipo penal de tráfico ilícito de migrantes. De hecho, así pasó en un caso en la ciudad de Arica que será revisado más adelante.

Como se adelantó, las sanciones de carácter penal que contiene este Decreto Ley se concentran en los delitos de ingreso y egreso fraudulento y clandestino, tipificados

5. La denominación de «objeto» de tráfico y no de víctima se deriva del protocolo contra el tráfico de migrantes, en el que se denomina así a los migrantes que ingresan bajo esta modalidad. Esto se recepcionó en Chile en la Ley 20.507, incorporando al Código Procesal el artículo 78 bis, en el que se estipulan medidas de protección para las víctimas de trata y las personas «objeto» de tráfico de migrantes.

6. Para más información, véase el artículo 45 del Decreto Ley 1094 de 1975.

7. Para más información, véase el artículo 70, 71, 72 del Decreto Ley 1094 de 1975.

8. Para más información, véase el artículo 73 del Decreto Ley 1094 de 1975. 
en los artículos 68 y 69 de dicho cuerpo legal. En ellos, se sanciona con penas privativas de libertad a quienes entran o intenten salir del país con documentos falsos, adulterados o de otra persona (artículo 68) o lo hagan clandestinamente, es decir, por paso no habilitado o infringiendo las prohibiciones que estipula el Decreto Ley (artículo 69).

Las disposiciones castigan penalmente a quienes ingresan o salen del país por paso clandestino o con documentación falsa. En ambos casos, se sanciona al migrante que realiza dicha acción. Son delitos de acción pública previa instancia particular y el legitimado activo para denunciar o querellarse es el Ministerio del Interior o las intendencias.

Antes del 8 de abril de 2011, fecha de entrada en vigencia de la Ley 20.507, en Chile no existía ningún delito que sancionara la actuación de un tercero frente a la migración irregular de un migrante. Solo se castigaba a los migrantes que incurrían en los tipos citados con conductas como ingresar por pasos clandestinos, no habilitados o siendo habilitados sin concurrir a la revisión del funcionario contralor del paso fronterizo; también a quienes, presentándose ante las autoridades, lo hacían con documentación exigida adulterada, la que podía tratarse de pasaportes, visas y cédulas de identidad dependiendo de las exigencias de ingreso al sujeto en particular derivado de su país de origen.

Estos tipos penales mantuvieron su vigencia luego de la tipificación del tráfico ilícito de migrantes, lo que ha contribuido a las dificultades interpretativas. En el primer caso de tráfico que se conoció en Chile, el ingreso se realizó con documentos falsos. Era perseguible la conducta del tercero que promovió o facilitó el ingreso ilegal con ánimo de lucro y la del migrante que lo hizo con dichos documentos. ${ }^{9}$

Tras los primeros ocho años de vigencia de este tipo penal en Chile, las figuras del Decreto Ley de Extranjería prácticamente han quedado en desuso, ya que las intendencias y el Ministerio del Interior no presentan las denuncias o, si lo hacen, se desisten. Se privilegia la persecución del traficante por sobre la del migrante en atención a los propios compromisos asumidos por Chile en la Convención de Palermo y el protocolo contra el tráfico de migrantes (artículo 5)..$^{10}$

Con atención a estas disposiciones del Decreto Ley de Extranjería, se debate el contenido del elemento normativo entrada ilegal, el que para la interpretación amplia

9. Primer Juzgado de Garantía de Santiago, RUC 1000848231-K, 13 de diciembre de 2012. En esta sentencia, el tribunal condena a los migrantes por ingreso fraudulento, en las otras dos a los traficantes por tráfico ilícito de migrantes.

10. Además, hay una razón práctica: aunque jurídicamente el migrante no es considerado víctima del tráfico de migrantes, sino que objeto, se requiere de su participación activa en los juicios a efectos de lograr prueba para la condena de los traficantes, lo que no sería factible si a la vez es imputado en los mismos hechos. 
se concreta con la infracción de cualquiera de los requisitos indicados en el Decreto Ley para el ingreso al país, mientras que para la concepción restrictiva se hace solo si el ingreso puede considerarse clandestino o fraudulento, de acuerdo con los artículos 68 y 69 .

El desuso de las normas vigentes con respecto a la conducta penalmente relevante del propio migrante y la relevancia del tercero que lucra con el ingreso ilegal, sujeto activo del tráfico, exigen una referencia al contexto normativo internacional, fuente de esta tipificación, lo que puede resultar un aporte en la búsqueda de respuestas.

\section{Influencia en Chile de la Convención de Palermo y el protocolo} contra el tráfico ilícito de migrantes por tierra, mar y aire

Chile suscribió la Convención de Palermo y sus protocolos el 15 de noviembre del 200o. Estos compromisos internacionales fueron promulgados en el país a través del Decreto Supremo 342 de 2004, momento en que se tomó el compromiso de realizar mayores esfuerzos para la persecución de la criminalidad organizada transnacional, especialmente en lo referente a los delitos de trata de personas y tráfico ilícito de migrantes.

Chile, como otros países, también replicó en su legislación interna los tipos penales de trata de personas y tráfico ilícito de migrantes, asumiendo la descripción típica confeccionada por quienes redactaron el proyecto de la Convención y los protocolos de Palermo. Debido a esta incorporación casi directa de lo redactado en los instrumentos internacionales, no hubo mayor análisis sobre si la figura respondía a las necesidades de cada región, si esta introducción de tipos penales obedecía a los límites constitucionales o a los principios del derecho penal asentados en sus derechos internos.

Así, por ejemplo, en países como España, el tipo penal de tráfico ilícito de migrantes se introdujo al Código Penal el 2000, y desde ahí ha tenido cuatro modificaciones en 2003, 2007, 2010 y 2015 (Pomares, 2015: 1). En cada una de ellas, se buscó adecuar la regulación correctamente a las exigencias internacionales, a las de la Unión Europea y a la realidad nacional. A la fecha, persisten las discusiones doctrinales acerca de la legitimidad de la protección del control de flujos migratorios o sistema migratorio mediante un tipo penal, como también las diferencias de opinión acerca del bien jurídico que justifica la sanción penal de lo que para algunos no es más que favorecimiento de la inmigración ilegal (Cancio y Maraver, 2006: 63).

En la región, en general, las tipificaciones del tráfico ilícito de migrantes son las mismas. No hay mayores cambios ni adaptaciones. Las principales diferencias están en si se sanciona solo el ingreso ilegal, también la salida o incluso, en algunos casos, también la permanencia. En Chile se sanciona la promoción o facilitación del ingreso 
ilegal. ${ }^{11}$ ¿Supone que ha de ingresarse al país? La lógica de la conducta parece exigirlo, pero la redacción no es clara (facilitar o promover la entrada ilegal). Por eso, hay que analizar la referencia típica completa, la conexión con los verbos rectores. Normalmente, el objeto de la norma ayuda a definir los elementos del tipo. En este caso, la falta de claridad al respecto demanda mayor atención aún frente a las exigencias típicas.

La Convención de Palermo y el protocolo contra el tráfico ilícito de migrantes entregan herramientas relevantes para interpretar el tipo penal, ya que describen el ingreso ilegal, el ánimo de lucro y otorgan pautas para resolver temas de competencia para la investigación y la persecución de este delito.

En lo que se refiere a la entrada ilegal, el artículo 3, letra b), del protocolo señala que por «entrada ilegal»se entenderá el paso de fronteras sin haber cumplido los requisitos necesarios para entrar legalmente en el Estado receptor, lo que parece estar en la línea de la interpretación que hemos llamado amplia. A continuación, se verá cómo se tipificó en Chile el tráfico y se recurrirá a los instrumentos descritos para facilitar su interpretación.

\section{Tipo penal de tráfico ilícito de migrantes en Chile}

El tipo penal de tráfico ilícito de migrantes en Chile, tras ocho años de discusión en el Congreso, quedó descrito de la siguiente manera:

Artículo 411 bis. Tráfico de migrantes. El que con ánimo de lucro facilite o promueva la entrada ilegal al país de una persona que no sea nacional o residente, será castigado con reclusión menor en su grado medio a máximo y multa de cincuenta a cien unidades tributarias mensuales.

La pena señalada en el inciso anterior se aplicará en su grado máximo si se pusiere en peligro la integridad física o la salud del afectado.

Si se pusiere en peligro la vida del afectado o si este fuere menor de edad, la pena señalada en el inciso anterior se aumentará en un grado.

Las mismas penas de los incisos anteriores, junto con la de inhabilitación absoluta temporal para cargos u oficios públicos en su grado máximo, se impondrá si el hecho fuere ejecutado, aun sin ánimo de lucro, por un funcionario público en el desempeño de su cargo o abusando de él. Para estos efectos se estará a lo dispuesto en el artículo 260.

El inciso primero describe el tipo básico, en el que se centra la discusión en torno al bien jurídico. Los incisos segundo y tercero presentan las hipótesis agravadas, en los que es claro que se tutelan además otros bienes jurídicos personalísimos. El inciso final fue incorporado por sugerencia de Juan Bustos, para quien las exigencias y

11. En el 411 ter también se sanciona la salida ilegal cuando el objetivo de la salida es la prostitución. 
sanciones para los funcionarios públicos debían ser mayores, generando la excepción de la exigencia de ánimo de lucro para estos sujetos activos. ${ }^{12}$ Esta misma excepción genera más dudas con respecto a la definición del tráfico de migrantes y su objeto de tutela, ya que al suprimir el ánimo de lucro la idea de comercio no parece central.

Desde abril de 2011 hasta diciembre de 2018, han ingresado a la Fiscalía de Chile 817 casos de tráfico ilícito de migrantes. ${ }^{13}$ Según cifras del Ministerio Público, el ingreso por este delito ha tenido un aumento exponencial desde su tipificación y supera con creces los ingresos por el delito de trata de personas, que en el mismo período presenta 37 casos formalizados en todo el país. ${ }^{14}$

Antes de continuar, es relevante puntualizar las diferencias y similitudes entre el tipo que aquí se estudia y la trata de personas, por las confusiones que existen acerca de los elementos de cada uno y la posibilidad de concursos entre ambos.

A grandes rasgos, el tráfico ilícito de migrantes requiere que los verbos rectores como promover o facilitar estén conectados con el cruce de fronteras, con el ingreso ilegal al país de un no nacional o residente. Los verbos rectores de la trata son captar, trasladar, acoger o recibir y no se relacionan necesariamente con cruce de fronteras, ya que estos pueden tener lugar tanto dentro como fuera del país y con respecto a nacionales o extranjeros. Esta es, sin duda, una de las diferencias fundamentales.

Los medios comisivos de la trata importan el vicio o la inexistencia de la voluntad de la víctima por cuanto requiere violencia, intimidación y abuso, entre otros. El tráfico no requiere medios comisivos de los que necesariamente se desprenda vulneración o inhibición de la voluntad del migrante..$^{15} \mathrm{El}$ ánimo de lucro debe estar presente en el tráfico de migrantes (a menos que el sujeto activo sea funcionario público) sin otras finalidades. En cambio, en la trata, las finalidades son de explotación, tanto sexual como laboral, lo que implica trabajos forzados, esclavitud y prácticas análogas. También la finalidad puede ser la extracción de órganos.

El ánimo de lucro del tráfico, según los tribunales chilenos, se satisface tanto con dinero como con cualquier otro provecho económico para el traficante. En este sentido, ciertamente una trata que implique cruce de fronteras, cuya finalidad sea la explotación laboral, podría ser subsumible también en un tráfico cuyo ánimo de lucro se satisface con el trabajo de los migrantes. Acá, la diferencia deberíamos fijarla en la

12. «Historia de la Ley 20.507», Biblioteca del Congreso Nacional, 2011, p. 117, disponible en bit. ly/3lUk19D.

13. Fiscalía de Chile, respuesta de solicitud de transparencia número 5856 del 31 de enero de 2019.

14. «Datos estadísticos», Ministerio del Interior de Chile, 2019, disponible en bit.ly/2JXxqk1.

15. En algunos de los casos que se analizaron, se evidencia engaño a los migrantes, por ejemplo, en cuanto a no correr riesgos en sus ingresos y luego ingresar por pasos no habilitados riesgosos, e incluso en ofertas de ingresos legales, que finalmente son ilegales. Aun así, el tipo penal no exige engaño, pero estando presente podría tratarse quizás de una situación concursal entre estafa y tráfico, o de estar presentes los demás elementos de la trata, podría serlo y no ser tráfico. 
finalidad del traficante. La idea es definir si esta era lucrar con el cruce ilegal de fronteras de los migrantes o la explotación de ellos bajo el estándar de trabajos forzados, esclavitud o prácticas análogas.

También podría haber situaciones en las que el tráfico sea un medio para cometer la trata de personas. Una vez realizado el cruce ilegal de fronteras y satisfecho el ánimo de lucro del traficante, los migrantes en situación de ilegalidad quedan entregados a su suerte, en un estado de vulnerabilidad que podría ser aprovechado por tratantes. La relación entre ambos delitos, sin duda, puede dar lugar a más combinaciones y debates, pero nos aleja del objetivo principal de este trabajo. Volveremos sobre el aumento de la migración en el país y los ingresos de este delito en Chile.

El alto número de ingresos de casos de tráfico ilícito de migrantes podría tener una de sus causas en la nueva realidad migratoria del país. Chile ha pasado de ser un país de origen de migrantes a un país de destino. En cifras, en 2016 se solicitaron 165.656 visas, lo que equivale a un aumento del 51,4\% en relación con 2015. Solo los solicitantes de visa aumentan año tras año, llegando a un número récord en el país en $2017^{16}$

Hasta marzo del 2019 se han dictado cuarenta y tres sentencias definitivas por el delito de tráfico ilícito de migrantes en Chile, la mayoría de ellas en procedimientos abreviados. Los juicios orales por este delito a la misma fecha han sido solo trece. Estas sentencias serán el universo dentro del que se analizará la interpretación que se ha dado al elemento normativo entrada ilegal, que se plantea a continuación con una sistematización en dos grandes grupos.

\section{El contenido de la entrada ilegal en la jurisprudencia chilena}

\section{Interpretación amplia de entrada o ingreso ilegal}

Como se anticipó, se han resuelto trece casos de tráfico ilícito de migrantes en juicios orales en el período entre abril de 2011 y marzo de 2019. Ocho de ellos han terminado con condenas y cinco con absoluciones. En la mayoría de los casos, la entrada ilegal ha sido justamente el motivo central del debate.

En el primero de los casos conocidos en juicio oral en Chile, en el que se condenó a un grupo de dominicanas por tráfico ilícito de sus connacionales al país, el ingreso se produjo por paso habilitado (aeropuerto) y con documentos válidos (pasaportes). Cabe preguntarse, ¿ cómo se configuró el ingreso ilegal? Se dio por acreditado porque las migrantes declararon una finalidad falsa al ingresar, señalando que venían a hacer turismo cuando su verdadera intención, acordada con las acusadas antes de ingresar,

16. «Estimación de Personas Extranjeras Residentes en Chile», Departamento de Extranjería y Migración de Chile, 2018, disponible en bit.ly/2WhGHpx. 
era venir a Chile a trabajar. Las acusadas fueron condenadas tanto por tráfico ilícito de migrantes como por asociación ilícita para cometer dicho delito.

Así, el Cuarto Tribunal Oral en lo Penal de Santiago señaló:

Una vez más las acusadas Amelfi Mota Pérez y Yasmil Hernández Pérez, a fin de burlar el sistema migratorio de Chile, promovieron y facilitaron la entrada ilegal a esta tierra de la ciudadana dominicana J.R.C., al hacerla ingresar como turista cuando realmente venía a trabajar, cobrándole una determinada cantidad de dinero por ello. En ese sentido, R.P.D. y J.R.C. ingresaron ilegalmente a Chile, toda vez que para entrar al Estado señalaron al personal de Control Migratorio del Aeropuerto que venían como turistas, portando dinero suficiente para vacacionar en Chile, siendo su real motivación la de trabajar en esta nación, a fin de obtener una mejoría de su situación económica. De esta manera, ambos entraron «engañando» al personal contralor de migración, al realizar una declaración falsa del motivo que los traía a esta República, vulnerando el sistema migratorio nacional. ${ }^{17}$

La segunda sentencia analizada, dictada por el Tribunal Oral en lo Penal de Santa Cruz, igualmente señaló que la declaración de una falsa finalidad de turismo por los migrantes que venían a trabajar era constitutiva de entrada ilegal. ${ }^{18}$

Esta sentencia fue criticada por Salinero (2019: 576), quien sostiene que al no ingresar por paso clandestino ni con documentos falsos no hay entrada ilegal. Todo esto asimilando el concepto de entrada ilegal a la comisión de los delitos del Decreto Ley de Extranjería, sosteniendo la interpretación restrictiva.

Señala que la declaración de una finalidad falsa no forma parte de los verbos rectores del tipo de tráfico y esta, por sí sola, no posee relevancia jurídico penal. Esto es cierto y correcto porque en este delito no se castiga al migrante ni a su mentira, se castiga al otro, al traficante, que promueve o facilita ese tipo de ingreso al país, en el que el migrante, a instancias del traficante, incumple la legislación ingresando en una calidad distinta a la que le exige la ley según su finalidad.

En el tercer juicio, en la ciudad de Arica, se siguió la misma interpretación antedicha, fundada principalmente en el Protocolo de Palermo en contra del tráfico ilícito de migrantes y en las normas del Decreto Ley de Extranjería y de su Reglamento, latamente citadas por el Tribunal Oral en lo Penal de Santa Cruz.

También se trataba de ciudadanos, en este caso ecuatorianos, que ingresaron por paso habilitado y con documentos válidos, pero declarando una falsa finalidad de turismo. La novedad de este fallo es la cita expresa y directa de las normas del Protocolo de Palermo:

17. Cuarto Tribunal Oral en lo Penal de Santiago, RUC 1001114184-1, RIT 287-2012, 13 de diciembre de 2012.

18. Tribunal Oral en lo Penal de Santa Cruz, RUC 1110028038-K, 8 de junio de 2015. 
En tanto, según el artículo 3 del Protocolo de Palermo contra el Tráfico de Migrantes, se entiende por tráfico de migrantes la «facilitación de la entrada ilegal al país de una persona no nacional ni residente, para obtener un beneficio material».

Cabe añadir que El Protocolo Contra el Tráfico Ilícito de Migrantes por Tierra, Mar y Aire que complementa la Convención de las Naciones Unidas Contra la Delincuencia Organizada Transnacional en su artículo 3, letra a), define «tráfico ilícito de migrantes» como la facilitación de la entrada ilegal de una persona en un Estado parte del cual dicha persona no sea nacional o residente permanente con el fin de obtener, directa $\mathrm{o}$ indirectamente, un beneficio financiero $\mathrm{u}$ otro beneficio de orden material. ${ }^{19}$

En el cuarto caso analizado, conocido como Los Paraguayos, se juzgó el ingreso de migrantes de esa nacionalidad que venían a trabajar a los fundos del conocido empresario y exsenador Francisco Javier Errázuriz, se terminó absolviendo a los dos acusados que enfrentaron el juicio por no acreditar su participación en los hechos. Se trataba de la encargada de recursos humanos y del supuesto captador, este último de la misma nacionalidad que los migrantes. Con respecto al principal imputado Francisco Javier Errázuriz, no se pudo realizar el juicio, ya que se encuentra sobreseído temporalmente por su estado de salud.

En materia de entrada ilegal, la sentencia es muy interesante, ya que entiende que se configura este elemento, aunque los migrantes ingresaron por paso habilitado y con documentos válidos. Esto, porque declararon falsamente una finalidad vacacional que no tenían, ya que se acreditó que desde antes de viajar habían acordado con los imputados la finalidad de trabajar en los fundos.

Las defensas argumentaron que, por el acuerdo del Mercosur, las personas de Paraguay podían venir como turistas y luego obtener permisos de trabajo, lo que es efectivo, pero también lo es con respecto a todos quienes ingresan como turistas, porque con la actual legislación migratoria la categoría migratoria es susceptible de cambios previo cumplimiento de los requisitos legales. Esto no obsta a que quien ingresa como turista deba realizarlo cumpliendo los requisitos de ingreso en dicha calidad.

Para resolver, el Tribunal Oral en lo Penal de Santa Cruz reconstruyó el sistema de requisitos de ingreso al país establecido por el Decreto Ley. Se señaló en la primera parte, en el artículo 2, que sujeta a los extranjeros que deseen ingresar al país a cumplir con los requisitos previstos para ello; en el artículo 15, que en su numeral 7 prohíbe el ingreso al país de extranjeros que no cumplan con los requisitos de ingreso; en el artículo 44, que establece lo que se entiende por turista, indicando las actividades que en general esa calidad comprende, que incluye como requisito el no tener propósito de inmigración, residencia o desarrollo de actividades remuneradas; en el artículo

19. Tribunal Oral en lo Penal de Arica, RUC 1300331670-4, 20 de noviembre de 2013. 
48, que prohíbe a los turistas desarrollar actividades remuneradas, salvo expresa autorización del Ministerio del Interior por períodos acotados; y en el artículo 74, que prohíbe a su turno dar ocupación a los extranjeros que no acrediten previamente su residencia o permanencia legal en el país o que están debidamente autorizados para trabajar o habilitados para ello. ${ }^{20}$

Por su parte, la defensa argumentaba que los migrantes paraguayos tenían un estatus especial debido al Tratado del Mercosur, alegación que el tribunal rechazó por entender que no se configuraba una excepción a las normas ya indicadas aplicables a todos los extranjeros. Estimó que solo daba la posibilidad de hacer más rápidos los trámites de visación, pero no los eximía de cumplir con los requisitos legales señalados.

Por último, en cuanto a la configuración de la entrada ilegal, adhiriendo a esta interpretación amplia que se había realizado por los tribunales chilenos hasta esa fecha, señaló:

La declaración manifestada por estos extranjeros al llegar a Chile de ser turistas, que era incompatible entonces con trabajar remuneradamente, como se ha establecido, no respondía a la realidad, pues su verdadera intención era venir al país para trabajar, inmediatamente y sin esperar permiso alguno, a cambio de contraprestaciones económicas en las empresas de las que era dueño o partícipe Francisco Javier Errázuriz Talavera, de acuerdo con la oferta que este les había realizado, a través de otros sujetos y por medio de una invitación escrita emitida con anterioridad a su viaje y recepcionada por ellos. ${ }^{21}$

Recién en el quinto juicio oral vemos una situación distinta a las anteriores, ya que los hechos tienen relación con migrantes de República Dominicana y de Colombia que fueron ingresados al país por pasos no habilitados, evadiendo los controles migratorios.

En este caso, se juzgó a un grupo de personas que ofrecía, mediante una agencia de viajes llamada Sky Travel en República Dominicana, viajes a Chile. A los migrantes se les transportaba hasta Pisiga, Bolivia, y luego se les ingresaba por la localidad de Colchane por pasos clandestinos del norte del país.

$\mathrm{Al}$ respecto, el tribunal señaló que:

Finalmente, todos los ciudadanos dominicanos ingresados a territorio nacional de la forma reseñada lo hicieron ilegalmente, ya que jamás controlaron su entrada en alguna frontera, por lo que hasta la actualidad su situación en nuestro país es irregular, lo que les ha provocado diversos perjuicios. ${ }^{22}$

20. Tribunal Oral en lo Penal de Santa Cruz, RUC 1110028038-K, RIT 31-2015, 8 de junio de 2015.

21. Tribunal Oral en lo Penal de Santa Cruz, RUC 1200236968-9, del 12 de marzo de 2013.

22. Tribunal Oral en lo Penal de Iquique, RUC 1300315720-7, 11 de febrero de 2015. 
Es interesante el razonamiento del tribunal en cuanto señaló que su situación migratoria irregular, consecuencia del ingreso clandestino, les ha provocado diversos perjuicios. En alguna medida, este razonamiento se puede vincular con lo sostenido por Salinero, quien señala que solo hay ingreso ilegal cuando se accede por paso no habilitado o clandestino, siendo lo relevante justamente la vulneración de los derechos de los migrantes que sufren una situación migratoria irregular. Pronto, esto se verá con mayor profundidad.

\section{Interpretación restrictiva de la entrada o ingreso ilegal}

El giro interpretativo comienza con una sentencia de Arica, en la que el tribunal entiende que el ingreso ilegal debe responder a una actividad del tipo «empresa delictual» para que este obedezca al cumplimiento de los compromisos asumidos por el Estado de Chile en Palermo.

En los hechos, los acusados fueron sorprendidos tratando de salir del país hacia Perú con una menor de edad, quien realizaba trabajos domésticos en su casa, oculta en el asiento trasero del vehículo, sin que con respecto a ella hubiese registro de su ingreso al país. Según lo declarado por la joven, la instrucción que le dieron los acusados para ingresar a Chile fue que caminara por el lado del control fronterizo, evadiéndolo.

El tribunal da un vuelco a las interpretaciones anteriores de ingreso ilegal, entendiendo que debe ingresarse clandestina o fraudulentamente para que se constituya dicho ingreso, y a esto debe sumarse el ánimo de lucro del sujeto activo, absolviendo en este caso por falta de ánimo de lucro:

Por su parte, la normativa nacional relativa al ingreso al país se encuentra, por cierto, protegida a través del Decreto Ley 1.094 de 1975, que establece los delitos de entrada fraudulenta y clandestina al país, donde el sujeto activo es el extranjero migrante que ingresa al país con documentos falsos, adulterados o expedidos a nombre de otra persona, o sencillamente de manera clandestina o por pasos no habilitados. ${ }^{23}$

Este fallo señala que quien promueve o facilita el ingreso clandestino o fraudulento puede castigarse como cómplice o encubridor de dichos delitos del Decreto Ley de Extranjería, visibilizando los conflictos que surgen de la vigencia de las normas penales del Decreto en paralelo con el delito de tráfico ilícito de migrantes.

Para salvar esta situación, el tribunal, por primera vez, puso en entredicho que el bien jurídico sea el sistema migratorio o el control de los flujos migratorios por parte del Estado, entendiendo que lo que lo diferencia de los tipos penales de ingreso clandestino y fraudulento del Decreto Ley es justamente la protección de algo más, que

23. Tribunal oral en lo Penal de Arica, RUC 1500472364-o, 16 de marzo de 2016. 
para este tribunal es la seguridad individual y la libertad personal, ambos emanados de la dignidad humana, lo que implica una interpretación más estricta del ingreso ilegal.

Esta interpretación disidente básicamente postula que el ingreso ilegal es solo aquel que contraviene las normas penales del Decreto Ley de Extranjería y no las infracciones administrativas del mismo, por lo que ingresar declarando una finalidad distinta a la real o ingresando sin la visa exigida por dicho cuerpo legal no es constitutivo de ingreso ilegal a efectos del tráfico. Esto respaldado por una visión del bien jurídico que se aleja del control de los flujos migratorios, y agrega la libertad y seguridad, derivadas de la dignidad humana, como bienes protegidos por esta figura.

Siguió esta interpretación restrictiva el Primer Tribunal del Juicio Oral de Santiago, que tiene competencia sobre la comuna de Pudahuel, lugar estratégico para este delito, ya que allí se encuentra emplazado el principal aeropuerto del país.

Este tribunal ha dictado dos sentencias en juicios orales de tráfico ilícito de migrantes. En la primera condenó y en la segunda absolvió. ¿Cuál fue la diferencia? El ingreso, ya que en el primer caso se intentó realizar con pasaportes de otras personas (no se materializó la entrada al país) en el aeropuerto y en el segundo se ingresó por paso habilitado, con documento verdadero, pero declarando finalidad falsa de turismo, hipótesis que no fue aceptada por este tribunal como constitutiva de ingreso ilegal.

La curiosidad que presenta el primer caso, en el que se condenó, trasciende a este trabajo, y está constituida por la condena sin que se produzca efectivamente el ingreso ilegal. En cuanto al ingreso, se trataba de niños ecuatorianos que viajaban con dos mujeres ecuatorianas adultas con quienes no tenían lazos familiares ni portaban documento que autorizara su viaje con ellas. Al ser controlados en aeropuerto, los funcionarios se percataron de que los niños viajaban con pasaportes de niños norteamericanos verdaderos, pero que no les pertenecían. ${ }^{24}$

El tribunal dio por acreditado el intento de ingreso ilegal, subsumible bajo el verbo rector facilitación, debido a que los niños no portaban sus pasaportes ni las mujeres que los acompañaban portaban documentos que los autorizara a viajar con ellos. Para ello, se citaron las normas del Decreto Ley de Extranjería y su Reglamento. En el juicio del fallo absolutorio, se conocieron también dos delitos de trata de personas con respecto a los cuales se condenó al acusado. El hecho número tres del fallo y la acusación era la imputación por tráfico ilícito de migrantes de un ciudadano indio que viajó a Chile con visa de turismo obtenida mediante declaración falsa en el consulado de su país de origen, ya que desde antes de obtenerla conocía que venía al país a trabajar en el restaurante Joyas de la India, el mismo en el que trabajaban las dos víctimas de trata de personas por las cuales se condenó.

24. Primer Tribunal Oral en lo Penal de Santiago, RUC 1600660322-3, RIT 106-2017, 11 de julio de 2017. 
El tribunal no es muy claro al señalar el motivo por el que el ingreso no es ilegal, pero es tajante en asegurar, al contrario de la jurisprudencia que le antecede, que la declaración falsa no es suficiente para que el ingreso sea calificado como ilegal: «Tal convenio internacional en su artículo 3 , letra b), expone que se entiende por entrada ilegal el paso de fronteras sin haber cumplido los requisitos necesarios para entrar legalmente en el Estado receptor».

En esta causa, se probó que Dhan Singh tenía la calidad de turista al ingresar a Chile el 7 de junio de 2013, por lo que cabe referir de manera tajante que su entrada a territorio nacional no fue ilegal. ${ }^{25}$

Este tribunal, citando las mismas normas del Protocolo de Palermo, entiende algo diferente a lo que entendieron los tribunales que fallaron con anterioridad. Por otra parte, indica que trabajar en el país sin permiso de trabajo es una infracción administrativa, lo que es cierto, pero no es lo que se estaba juzgando en el caso. Lo que se puso ante conocimiento del tribunal fue la conducta del tercero (sujeto activo del delito) que promovió o facilitó su ingreso ilegal con ánimo de lucro al país.

Tras estas sentencias del Primer Tribunal Oral en lo Penal de Santiago, se dictaron cuatro sentencias en juicio oral por el delito de tráfico ilícito de migrantes, una por el Tribunal Oral de Osorno, en la que se condena por tráfico y por trata, en la hipótesis de ingreso por paso habilitado con documentos verdaderos, pero con declaración de finalidad falsa; una absolutoria del Cuarto Tribunal Oral de Santiago, en la que se mantuvo su interpretación amplia del ingreso ilegal, citada en el primer fallo ya analizado, pero en la que no se establece la culpabilidad de los acusados; dos en Arica de ingresos ilegales por pasos no habilitados; y una en Chillán, en la que se sigue y se cita la interpretación restrictiva del Primer Tribunal Oral en lo Penal de Santiago.

Efectivamente, con respecto al resultado típico, no se cumple con la «entrada ilegal» que requiere el tipo penal respectivo porque quedó acreditado que las supuestas víctimas, si bien ingresan al país siguiendo las instrucciones de los acusados y señalando que son turistas, por recomendación de Padilla, esto no puede ser considerado como una «entrada ilegal» en los términos que exige el tipo penal al tenor del artículo 6 del Decreto Supremo 594/1984 que contiene el Reglamento de la Ley De Extranjería ya transcrito, ya que, en este caso, los ciudadanos ecuatorianos ingresan por lugar habilitado (paso Chacalluta) con la documentación pertinente y sin que haya sido probada alguna causal de prohibición o impedimento para que estas personas ingresaran.

El fallo sostiene que este delito es pluriofensivo, por cuanto además del control migratorio protege la seguridad individual y la libertad personal, emanados de la dignidad de la persona humana, mismo razonamiento del Primer Tribunal Oral de Santiago. Lo distinto es que este tribunal entiende que el ingreso ilegal es el resultado

25. Primer Tribunal Oral en lo Penal de Santiago, RUC 1300508178-K, RIT 208-2017, 22 de enero de 2018. 
típico y no el elemento normativo del tipo, por lo que no podría haber condenado, como lo hizo el Primer Tribunal Oral por un ingreso ilegal tentado.

\section{Búsqueda de sentido del elemento normativo en las sentencias de la Corte Suprema}

En marzo de 2019, la Corte Suprema falló por primera vez un recurso de nulidad en un caso de tráfico ilícito de migrantes. Son dos sentencias, pero se refieren a un solo caso, el que fue conocido y juzgado por el Tribunal Oral en lo Penal de Arica, en dos juicios, pero se trataba de una sola organización. ${ }^{26}$ Esta se dedicaba a traer ciudadanos de República Dominicana a Chile, pasando por Ecuador, Perú y Bolivia, los que eran ingresados por pasos clandestinos al país y a quienes la organización cobraba una suma de dinero en efectivo. ${ }^{27}$

Este grupo organizado ingresó ilegalmente a Chile aproximadamente a un centenar de personas a través de pasos clandestinos, lo que implicó un riesgo para sus vidas e integridad física y psíquica. Tanto así que uno de los migrantes fue víctima de la detonación de una mina antipersonal, la que le provocó la imputación de una de sus piernas.

Los recursos de nulidad fueron presentados por las defensas de todos los condenados y las causales principales de los recursos, que influyen en el análisis de este delito, fueron, en primer lugar, que se trataba de delitos cometidos por extranjeros en contra de extranjeros fuera de Chile, por lo que nuestros tribunales no tenían jurisdicción para conocer y juzgar.

En segundo lugar, que se les condenó por un delito de asociación ilícita y se les impuso la pena de las asociaciones que cometen crímenes, alegando la defensa que el tráfico ilícito de migrantes es un simple delito, por lo que la pena de la asociación estaba mal determinada. Con estos dos argumentos que sustentaban las causales principales de las nulidades, la Corte Suprema de Chile se pronunció por primera vez acerca del delito en estudio.

Con respecto al primer argumento, la Corte resolvió que Chile sí tiene jurisdicción para conocer casos de tráfico ilícito de migrantes debido al artículo 6, número 8 , del Código Orgánico de Tribunales. En virtud de esta norma, se remite a la descripción que hace la Convención de Palermo del delito de tráfico de migrantes (artículo 3, letra a), y entiende que Chile puede y debe conocer de aquellos delitos descritos en las Convenciones Internacionales a las que se ha obligado.

26. Esto sucedió porque se solicitó la extradición de esta agrupación y llegaron por grupos en fechas distintas. Frente a ello, la defensoría solicitó realizar un primer juicio con el grupo que llegó primero y luego se realizó el segundo juicio con los líderes que fueron extraditados después.

27. Corte Suprema, rol 32.695-2018 y 331-2019, 5 de marzo de 2019. 
Luego, para que no queden dudas acerca de la jurisdicción de los tribunales nacionales, la Corte indica que la propia Convención de Palermo sostiene un tipo de principio universal, ${ }^{28}$ en cuanto entiende que cada Estado suscriptor debe conocer y juzgar hechos que se comprenden dentro de los crímenes transnacionales, y de no hacerlo, tiene la obligación de extraditar. Expone justamente que, en este caso, Perú, país de residencia de gran parte de los miembros de la organización, los extraditó hasta Chile, por lo que asintió en que ellos fueran juzgados en nuestro país. Hasta aquí esta discusión, que da para profundizar, pero nos aleja del objeto de estudio.

Posteriormente, con el objetivo de determinar si la asociación ilícita que se juzgaba recaía sobre simples delitos o crímenes y, en consecuencia, de si la pena estaba correctamente determinada, la Corte se avoca a la búsqueda del bien jurídico tras el tráfico ilícito de migrantes. Esto porque la pena es diferente entre la figura básica del tráfico, del inciso primero y las agravadas. Aquí, las sentencias se vuelven relevantes para el tema en estudio.

En la búsqueda del bien jurídico, cita la historia de la Ley 20.507 indicando que el propio legislador señaló que el bien jurídico era el control de la normativa migratoria en cuanto al control de las fronteras, pero en opinión de la Corte «ello no es aceptable, al menos en forma absoluta», ${ }^{29} \mathrm{y}$ para fundar esta posición cita una sentencia del Tribunal Supremo español de 1998.

El fallo citado resulta ser de una época en la que, en España, al igual que en Chile, aún no estaba tipificado el tráfico ilícito de migrantes. Los hechos son de 1990 y se refieren a unos ciudadanos de República Dominicana que ingresaban con pasaportes de religiosas a mujeres dominicanas, y luego de su ingreso ilegal a España las presionaban para que ejercieran la prostitución y pagaran las deudas que tenían con los acusados por sus viajes.

El caso llegó al Tribunal Supremo español a fines de la década del noventa para ser revisado, ya que el artículo con el que se había sancionado dicha promoción de la inmigración ilegal había sido derogado. Este era el artículo 499, letra a), número 2, del Código Penal de 1983.

La cita textual de una parte de esa sentencia, por parte de la Corte Suprema chilena, se refería al bien jurídico tras la promoción de la prostitución, delito tipificado en el artículo 455 del Código Penal español de la época, por el que finalmente fueron condenados los acusados de ese caso y que se refería a la dignidad. Es por ello que la Corte Suprema suma la dignidad al control de los flujos migratorios.

28. La Corte Suprema intenta asimilar, de alguna manera, el principio de jurisdicción universal presente en los crímenes de lesa humanidad, a lo que indica el artículo 15 de la Convención de Palermo. Este, más bien, es la materialización del principio «juzga o extradita» y no de jurisdicción universal. El primero es aplicable a crímenes de lesa humanidad y el segundo a delitos transnacionales.

29. Corte Suprema, rol 32.695-2018 y 331-2019, 5 de marzo de 2019, considerando 16. 
Incluso en la actualidad, el tipo español no es asimilable al chileno, ya que el ánimo de lucro no es una exigencia típica de la figura básica. Menos aún lo era en sus versiones anteriores a 2015, en que la trata de personas y el tráfico ilícito de migrantes estaban descritos en el mismo artículo.

Si la búsqueda se hubiera centrado en sentencias del Tribunal Supremo español aplicando el artículo 318 bis, habría advertido que también en España hay diferentes posturas acerca del bien jurídico tutelado, las que van desde el bien jurídico colectivo control de flujos migratorios o sistema migratorio hasta los derechos de los migrantes, pasando por la dignidad humana.

Pero en el tema que nos interesa, el Tribunal Supremo español interpreta el ingreso ilegal de manera amplia, entendiendo que, por ejemplo, las declaraciones de finalidades falsas o la obtención de visas con documentos falsos constituyen ingreso ilegal.

Habría sido un aporte a la discusión que la Corte Suprema mediante sendos argumentos jurídicos criticara la legitimidad de que la protección de fronteras o el control de flujos migratorios sea el bien jurídico de este delito, entendiendo que, por ejemplo, no cumple con algunos principios del derecho penal, pero se centró en la búsqueda de otro bien jurídico encontrándolo en la dignidad humana.

Las sentencias confirman las penas de la asociación ilícita como dedicada a crímenes, ya que, en todos los casos probados en los juicios en cuestión, los migrantes estuvieron en riesgo y vieron afectados bienes jurídicos personalísimos, de lo que se desprende que el inciso segundo y tercero del 411 bis son figuras que sancionan una actividad que provoca un riesgo concreto, a la salud y/o a la vida de los migrantes $y$, en este sentido, se justifica la pena agravada con respecto a la figura básica.

Para finalizar, independiente de que estas sentencias no resuelven el problema planteado, resultan interesantes por tratarse de los únicos pronunciamientos al respecto de nuestra Corte Suprema, en las que esboza su inclinación por una de las posturas acerca del bien jurídico que se tratará.

\section{Tráfico ilícito de migrantes en la doctrina chilena: Tesis sobre el bien jurídico ${ }^{30}$}

La doctrina nacional se ha centrado en la búsqueda del bien jurídico tutelado en esta nueva figura para intentar, desde ahí, interpretar los elementos del tipo penal. De lo publicado hasta ahora en Chile, se presenta una muestra de las principales discusiones acerca del bien jurídico, que se agrupa en tres corrientes: quienes sostienen que se tutela el sistema migratorio, que aquí hemos llamado control de flujos migratorios;

30. Contribuyen con una visión panorámica de las distintas interpretaciones del bien jurídico en el tráfico ilícito de migrantes Segovia (2013: 219), Duarte (2015: 163), Martínez (2007: 8);,Pérez (2008: 335) y Cancio y Maraver (2006: 63). 
quienes abogan por la integridad moral o la dignidad; y, por último, los que justifican la existencia de este tipo penal en la protección de los derechos de los migrantes.

\section{Protección del sistema migratorio o control de los flujos migratorios}

En el primer grupo encontramos a Matus y Ramírez (2014: 195), quienes indican que el bien jurídico es la protección de la regulación de la entrada al país. Apoyan su postura principalmente en el argumento histórico, por cuanto en la historia de la Ley 20.507 se plasma en acta la opinión de la diputada informante del proyecto y una de sus autoras, María Antonieta Saa, sobre el tráfico ilícito de migrantes como delito en contra del Estado, en el que se vulneran las leyes migratorias. Esa sería la diferencia principal de la trata de personas, que sería un crimen en contra de ellas que explica la diversa gravedad en sus penas. ${ }^{31}$ Esta postura fue asumida por la mayoría de quienes votaron en dicha sesión, ya que esto justificaría las penas de menor intensidad en el tráfico con respecto a las penas más altas en la trata, donde se vulneran siempre los bienes jurídicos personalísimos.

Si bien el elemento histórico y la diferencia de penas con base en la tutela de bienes distintos son argumentos de peso para esta postura, no deja de ser confuso que ambos delitos (tráfico y trata) estén bajo el mismo acápite de los delitos en contra de las personas en el Código Penal.

Matus y Ramírez agregan que en el inciso segundo y tercero del artículo 411 bis se sumarían bienes jurídicos como la integridad física, la salud o la vida, ya que se concibe al migrante como afectado por un delito de peligro concreto contra estos bienes y de peligro abstracto en contra de los mismos bienes tratándose de menores de edad.

En la misma línea, Segovia (2013: 236) y Gajardo y Torres (2011: 233) entienden que se protege el interés estatal en el control del sistema migratorio, lo que se traduce en utilizar el derecho penal para este tipo de control. Los argumentos que sostienen esta posición van desde el elemento histórico señalado, el sistemático, de acuerdo con el cual al remitirse al Decreto Ley de Extranjería se busca la protección de las fronteras, hasta un argumento de texto legal, por cuanto la redacción del tipo penal básico no exige afectación a ningún bien jurídico personalísimo para configurar el inciso primero del artículo 411 bis.

Avilés (2017: 13), en su tesis de magíster de la Academia de Carabineros, señala que el bien jurídico es el sistema migratorio del Estado sin profundizar en el fundamento de esta afirmación, pero destacando que este es el argumento por el que a los sujetos traficados no se les considera víctimas, como sí se les considera en el caso de la trata de personas. El punto también es relevante, ya que incluso en el protocolo contra el tráfico se habla de «objetos» de tráfico y no de víctimas del mismo.

31. «Historia de la Ley 20.507», Biblioteca del Congreso Nacional, 2011, p. 46, disponible en bit.ly/3lUk19D. 
Bascuñán (2017: 8), en su presentación en las III Jornadas de Derecho Penal del Norte en la ciudad de Arica, señaló que lo que el tráfico ilícito de migrantes tutela es el sistema migratorio del Estado.

Esta misma postura siguen en España autores como Cancio y Maraver (2006: 66), para quienes lo que se busca proteger es el control de los flujos migratorios, criticando a quienes sostienen que son otros los bienes tutelados, sobre la base de la imposibilidad o ilegitimidad de que el sistema migratorio o el control migratorio pueda ser el bien jurídico.

Autores como Pérez Esteban (2008: 356) señalan que realmente el artículo 318 bis español no tipifica el tráfico ilícito de migrantes, sino que lo que se sanciona es una especie de promoción o facilitación de la inmigración ilegal, esto desde que se suprimió el ánimo de lucro como exigencia subjetiva adicional.

\section{Protección a bienes jurídicos personalísimos: la dignidad humana y la integridad moral ${ }^{32}$}

En un segundo grupo están aquellos que entienden que se tutelan bienes jurídicos personalísimos, específicamente la dignidad y/o la integridad moral del migrante. Parten del significado mercantil de la palabra tráfico y se considera esencial la exigencia de ánimo de lucro (Cárdenas, 2011: 453). La principal expositora en Chile de esta opinión es Cárdenas, quien en diversos foros ha señalado que el trato del migrante como mercancía es atentatorio de su integridad moral, que sería el bien jurídico tras el tráfico ilícito de migrantes. Fernández y Mardones, como se señalará en la misma línea de bienes jurídicos individuales, postulan que se tutela la dignidad.

Resulta interesante el planteamiento del tráfico como negocio, a diferencia del tráfico como traslado. Sin embargo, para llegar a esta interpretación deberíamos sostener que el objeto del negocio son los migrantes y no su ingreso ilegal. Solo así podríamos obtener como consecuencia que se afecta su integridad moral y/o su dignidad, debido al trato de los traficantes hacia el migrante como objeto y no como sujeto que decide migrar y, en algunos casos, pagar por su ingreso ilegal..$^{33} \mathrm{El}$ pago como prueba del ánimo de lucro del sujeto activo se verá más adelante.

Para entender a qué se refieren los autores al sostener que se tutela la integridad moral, en Chile ha sido analizada en referencia a las modificaciones de delitos de tortura. Así, Durán (2019: 204) la define como un nuevo bien jurídico incorporado

32. Se señala como copulativos o alternativos, ya que para algunos autores la integridad moral sería la expresión de la dignidad como bien jurídico penal, pero para otros se trata de conceptos distintos, y se protege una o la otra.

33. De los casos analizados, podemos observar que en la mayoría de ellos los migrantes pagan con dinero su ingreso a los traficantes, en otras con trabajo. 
al Código Penal chileno a propósito de dicha modificación legal. En España, se ha señalado que esta sería:

El derecho de la persona a ser tratada conforme a su dignidad, sin ser humillada o vejada, cualquiera que sea la circunstancia en las que se encuentre y la relación que tenga con otras personas. Razón por la cual, este bien jurídico autónomo puede ser también un factor de agravación de otros delitos, que ya lo tienen en cuenta entre sus tipos cualificados; pero cuando no es así, los actos que lo lesionan pueden entrar en concurso con otros delitos (Arroyo, 1997: 418).

En España, la relación entre la integridad moral y la dignidad ha sido ampliamente debatida a propósito del título dedicado a los delitos contra la integridad moral. ${ }^{34}$ El punto de si la integridad moral es o no equivalente a la dignidad, o si se trata de conceptos distintos, se encuentra analizado también a propósito de los bienes protegidos en la trata de personas. La integridad moral y la dignidad humana son bienes jurídicos que se han entendido como tutelados por el delito de trata de personas. Moya (2016: 1) sistematiza tres posiciones acerca del bien jurídico, tanto en España como en Chile: la dignidad, la integridad moral y la libertad, además de la postura de que se trata de un delito pluriofensivo.

En esta parte, se agrupa tanto a quienes sostienen que se protege la integridad moral como la profesora Cárdenas, como a quienes postulan que sería la dignidad de la persona humana, como Mardones y Fernández, por la estrecha vinculación entre ambos conceptos.

Para Mardones y Fernández (2011: 13), el bien jurídico es la dignidad de la persona humana, entendiendo que la razón de la Ley 20.507 es el control de los flujos migratorios, pero argumentando que este no puede ser el bien jurídico protegido, ya que no se trata de un bien individual, sino colectivo, que no puede ser tutelado en un derecho penal de un Estado democrático de derecho:

Ahora bien, aceptando que la ratio legis del precepto es el control de los flujos migratorios, no puede ser el bien jurídico protegido, ya que de lo contrario se encierra un peligro de corte totalitario, en el que, como nota característica, el bien jurídico protegido pierde cualquier referencia individual para funcionalizarse de acuerdo con las necesidades colectivas [...] En esta línea y admitiendo las intenciones explícitas del legislador, puede interpretarse que la ratio legis del precepto legal es el control de los flujos migratorios, pero no el bien jurídico penal protegido.

34. Comprende los artículos referidos al trato degradante, acoso laboral, acoso inmobiliario y violencia familiar habitual (artículo 173); tortura (artículo 174); atentado contra la integridad moral (artículo 175); comisión por omisión por autoridad o funcionario del delito contra la integridad moral (artículo 176); y concurso en los delitos contra la integridad moral (artículo 177). 
Sobre la crítica de los autores frente a que el bien jurídico no puede ser colectivo y la sugerencia de que se trata de la ratio legis, la misma situación se plantearía con respecto a varios delitos en Chile, sobre todo de las últimas décadas, donde lo que se busca tutelar son bienes colectivos, como los delitos medioambientales, los que protegen el patrimonio cultural, el tráfico de drogas, el lavado de activos, entre otros. Esto no ha sido un obstáculo para su vigencia y persecución.

En España, Villacampa (2011: 265) y Pérez (2004: 173) realizan una interpretación del bien jurídico en este sentido. Se protegería la dignidad de las personas, prohibiendo su comercialización. Los migrantes son objetos y no sujetos que deciden migrar e ingresar a algún Estado.

De acuerdo con las exigencias del tipo penal, solo la trata de personas requiere que el consentimiento no exista o esté viciado, según se desprende de sus medios comisivos. En la descripción del tráfico no hay exigencias en ese sentido, lo que tampoco anula la posibilidad de que en algunos casos los migrantes sean engañados y deba analizarse la posibilidad de concurso con la trata o con la estafa.

En los casos reseñados se evidencian situaciones en las que los migrantes han sido engañados, creyendo que están pagando por un servicio de agencia de viajes y que su ingreso será legal, ${ }^{35} \mathrm{o}$ que pagan por un servicio de trámite de visado para venir a Chile y no saben que se está realizando con documentos adulterados. ${ }^{36}$

En la trata, al ser suprimida o viciada la voluntad del sujeto y al existir finalidad de explotación de diversas índoles, incluida la esclavitud, la víctima es tratada como objeto, suprimiéndose su calidad de persona deliberante y, en consecuencia, podría llegar a establecerse una vulneración a su dignidad o integridad moral. En el tráfico, al no desprenderse del tipo ninguna exigencia de menoscabo a la voluntad del traficado ni finalidades de explotación, el sujeto es deliberante, en cuanto decide su traslado a otro país. ${ }^{37}$ En este sentido, no se comparte la visión de que el tráfico protegería la dignidad del migrante ni su integridad moral, por lo menos en la hipótesis básica, que es la que nos ocupa.

Sociológicamente, se ha planteado esta tendencia a la victimización del migrante por parte de la criminalización del tráfico como una forma de invisibilidad de la voluntad de migrar, dejando de ver al migrante como una persona que decide ingresar de esta manera, ya que la forma legal no está dentro de sus posibilidades (por la razón

35. Caso conocido mediáticamente como Sky Travel, agencia de viajes de República Dominicana que ofertaba viajes a Chile. Se investigó y juzgó en Iquique, previa extradición de los imputados.

36. En el caso de los paquistaníes, primer caso fallado en Chile por tráfico ilícito de migrantes, no todos los migrantes sabían la forma de obtención de sus visas. Incluso, algunos declararon que compraron un viaje a Estados Unidos y fueron traídos a Chile bajo ese engaño.

37. De existir engaño acerca de la calidad del ingreso y establecerse las finalidades de la trata, podría ser una trata de persona y no tráfico, o bien podrían existir concursos. 
que sea) y dejándolo como una víctima de una situación que no decide (Dias, 2017: 544).

\section{Protección de los derechos de los migrantes}

La tercera corriente está conformada por las opiniones de quienes entienden que lo tutelado es la posibilidad del pleno ejercicio de los derechos de los migrantes, lo que de alguna forma se ve mermado por el ingreso ilegal. En esta línea, el profesor Maldonado (2012: 103) señala que lo protegido no es el mero interés público en el control fronterizo, sino que está relacionado con la posibilidad del ejercicio pleno de derechos cuando el migrante está en una situación desmejorada o irregular.

En un sentido similar, el profesor Salinero (2019: 570), en su comentario a la Sentencia del Tribunal Oral de Santa Cruz, en la que se condenó a un empresario de la sexta región por tráfico ilícito de migrantes bolivianos, ${ }^{38}$ entiende que es un delito pluriofensivo en el que, por una parte, se tutela el orden público y, por otra, los derechos individuales de los extranjeros inmigrantes como víctimas debido a la imposibilidad en la que quedan de un ejercicio pleno de sus derechos por la situación migratoria irregular.

Esta postura se relaciona con interpretaciones como la de Serrano-Piedecasas y Rodríguez en España, quienes no comparten que el sistema migratorio sea lo protegido tras esta figura delictual. Para Rodríguez (2001: 58), el bien jurídico son los derechos de los ciudadanos extranjeros, entendidos como «un espacio vital de desarrollo», la que no es posible cuando su situación migratoria es irregular.

Si el bien jurídico es la vulneración de los derechos de los migrantes, se produce la inconsecuencia de que el mismo Estado que persigue a los traficantes es quien, a la vez, no les reconoce una situación regular a los que ingresaron de forma ilegal. Es el propio Estado quien pone en una situación de vulnerabilidad al migrante que ingresa de manera ilegal, por lo que no parece lógico que criminalice a quien promueve o facilita esta situación y, a la vez, con ello busque proteger los derechos de los ciudadanos extranjeros. Más bien parece un eufemismo para no reconocer que lo que se busca es un fuerte control de las fronteras a través del derecho penal.

En la Convención de Palermo, cuya finalidad es la persecución de la criminalidad organizada transnacional, no se encuentran argumentos para sostener esta posición, sobre todo al considerar que el propio protocolo señala a los migrantes como objeto del tráfico a diferencia de las víctimas de trata. En la historia de la Ley 20.507, no hay registros de que se haya buscado proteger los derechos de los migrantes ni hasta el momento hay mociones de modificación legal en ese sentido, a diferencia del tipo penal español que, luego de diversas modificaciones, termina declarando que protege

38. Tribunal del Juicio Oral en lo Penal de Santa Cruz, RUC 1200236968-9, 12 de marzo de 2013. 
los derechos de los ciudadanos extranjeros. A modo de crítica, este grupo de derechos no está claramente delimitado, ni tampoco es pacífico que un grupo de derechos no definido pueda ser bien jurídico penal.

En el caso chileno, para sostener esta posición, a efectos de cumplir con la certeza jurídica se tendría que identificar claramente cuáles posibilidades de ejercicio de derechos son las que se estarían impidiendo con el delito de tráfico de migrantes, y así identificar el bien jurídico con una posibilidad de ejercicio concreta que está corriendo un riesgo o sufriendo un daño evitable o castigable vía derecho penal.

\section{Conclusión: Contenido del elemento normativo entrada ilegal de acuerdo con la tesis asumida del bien jurídico}

El contenido de la entrada ilegal en Chile ha sido principalmente abordado en la jurisprudencia con algunas menciones en la doctrina nacional. La doctrina, más bien, se ha centrado en el bien jurídico tutelado, lo que a su vez ha servido como sustento para las interpretaciones jurisprudenciales del elemento normativo.

Los autores que interpretan en forma amplia la entrada ilegal, en el sentido de que cualquier contravención a la normativa migratoria daría lugar a ella, sostienen que el bien jurídico es colectivo, y se trata del control de los flujos migratorios por parte del Estado. Este se vería afectado con la vulneración de cualquiera de los requisitos migratorios vistos en la primera parte. Esta ha sido la postura seguida por la mayoría de las sentencias que se analizaron en la primera parte.

Los autores que interpretan restrictivamente el ingreso ilegal, lo fundan en la protección de bienes jurídicos personalísimos como la integridad moral y/o la dignidad, o los derechos de los ciudadanos extranjeros. Ninguno de estos bienes jurídicos se vería en riesgo ni dañado al ingresar por paso habilitado, con documentos verdaderos, tan solo declarando falsamente una finalidad u habiendo obtenido visas con documentos falsos. La jurisprudencia minoritaria que ha seguido esta línea entiende que solo se produce la entrada ilegal al realizar las conductas de los artículos 68 y 69 del Decreto Ley de Extranjería, esto es ingresando en forma clandestina o fraudulenta.

En los casos de ingresos clandestinos, se vulneraría alguno de los bienes personalísimos ya indicados debido al riesgo que implica para las personas. En los supuestos fraudulentos, la razón es un poco menos comprensible. Se tratan como equivalentes cuando los riesgos para las personas en ambas hipótesis no lo son. Claramente, no corre el mismo riesgo quien ingresa por el desierto, atravesando campo minado, que quien lo hace por paso habilitado con un documento falsificado.

Para reforzar la posición acerca del ingreso fraudulento es útil la tesis de Salinero, para quien la entrada ilegal, que satisface la exigencia típica, es aquella que deja al migrante en una situación irregular en la que exista una imposibilidad de ejercicio para sus derechos. Esto sí se lograría con un ingreso fraudulento. 
Para este autor, la entrada ilegal se configura por los ingresos clandestinos y fraudulentos, pero no por las declaraciones falsas al funcionario contralor, ingresando como turista, cuando la verdadera intención es trabajar. Tanto el ingreso como turista y la mutación de turista a trabajador son posibles y, en ambas situaciones, el migrante está en una situación migratoria legal, en la que no se vería afectada la capacidad de ejercicio de sus derechos.

Las dos interpretaciones de entrada ilegal, amplia y restrictiva, obedecen a distintas posiciones acerca del bien jurídico, colectivo o personalísimo. La claridad acerca del bien tutelado restringiría las variables interpretativas de la entrada ilegal, acción sobre la que recaen los verbos rectores promover o facilitar. Esto facilita la comprensión de la conducta típica.

Si bien el tráfico y la trata de personas se contemplan bajo el mismo título octavo de los crímenes y delitos en contra de las personas, las disposiciones legales y sus finalidades permiten establecer que la figura básica (inciso 1 del artículo 411 bis) solo protegería el sistema migratorio del Estado. Las figuras agravadas de los incisos segundo y tercero adicionan la afectación o riesgo de la integridad física y la vida, y ahí se transforma en pluriofensivo.

Gramaticalmente, lo que se promueve o facilita es la entrada ilegal. Esta debe entenderse a contrario sensu de entrada legal, que es aquella que se realiza conforme a la legislación del país receptor. Con un criterio histórico, la discusión más relevante acerca del punto se sostuvo en el Congreso a propósito de la diferencia de penas entre la trata y el tráfico por la mayor gravedad de la primera debido a la afectación de bienes jurídicos personalísimos. Se asume que la figura básica de tráfico solo afectaba el sistema migratorio y no bienes personalísimos. Por último, la visión sistemática a la que se recurre, con la revisión de la Convención de Palermo y del protocolo contra el tráfico, muestra que se busca la persecución de la criminalidad organizada transnacional y no se reconoce al migrante «objeto» de tráfico como sujeto ni como víctima. Luego, por el Decreto Ley de Extranjería, que tipifica delitos de inmigración ilegal cometidos por el propio migrante, se evidencia que la figura del tráfico amplía la persecución al tercero que lucra con los ingresos ilegales.

Esta interpretación es coherente con la descripción típica, basada en la exigencia de promoción o facilitación de la entrada ilegal, la que se ha entendido, según lo prescrito en Palermo, como toda aquella en que no se cumplen con los requisitos de entrada exigidos en la ley del país receptor. En efecto, el ánimo de lucro no es necesario cuando el sujeto activo es un funcionario público. En cambio, el elemento del tipo entrada ilegal no puede faltar en ninguna hipótesis.

En el tráfico ilícito de migrantes se castiga justamente la promoción o facilitación del ingreso ilegal a un país. Si se castigara a quien promueve o facilita el ingreso legal con ánimo de lucro, no tendría sentido la prohibición, ya que el migrante podría ingresar sin necesidad de un traficante. Si aquel sucumbe ante una oferta de otro para 
ingresar (legalmente), esta conducta contiene implícito un engaño, que podría ser constitutivo del delito de estafa, pero no de tráfico ilícito de migrantes.

En este sentido, el elemento normativo juega un papel fundamental en la tipicidad de una conducta que pretendemos entender como tráfico ilícito de migrantes, ya que este delito, a diferencia de la trata de personas, siempre requiere del cruce de fronteras y que este sea ilegal.

La entrada ilegal delimita los verbos rectores: «el que promueve o facilita el ingreso ilegal» es el núcleo fundamental de este tipo penal, lo que lleva a concluir que el verdadero bien jurídico, apropiado o no, es el control de los flujos migratorios por parte del Estado.

Restringir el tráfico ilícito de migrantes solamente a la promoción o facilitación de los delitos de ingreso clandestino y fraudulento del Decreto Ley de Extranjería sería desconocer los compromisos asumidos en la Convención de Palermo y sus protocolos, ya que si solo se castiga la promoción o facilitación de esos ingresos, no habría existido la necesidad de tipificar un nuevo delito de tráfico ilícito de migrantes. Hubiera bastado con la imputación a título de cómplice o coautor de esos delitos, posibilidad que existía en nuestra legislación antes de abril de 2011 y que se mantiene vigente a pesar de su desuso.

Las tesis restrictivas, basadas en protección de bienes jurídicos personalísimos, en cuanto a entender que se protege la integridad moral o dignidad, confunden la trata de personas y el tráfico de migrantes al entender que en ambos hay exigencias de anulación o vicio de la voluntad más explotación, las que transforman al sujeto en objeto. Esto es cierto en las hipótesis de trata con finalidad de esclavitud, en la que el ser humano claramente pasa a ser tratado como objeto, pero no es una exigencia del tráfico en el que lo que se negocia es la entrada ilegal y no una venta de personas.

En segundo lugar, confunden la prohibición de criminalizar al migrante con la obligación de tipificar el tráfico ilícito de migrantes. Los Estados, al suscribir Palermo, se obligaron a no criminalizar al migrante, y esto se cumple al no perseguirlos por los ingresos ilegales propios del tráfico ilícito de migrantes. Si no se puede criminalizar al migrante por el ingreso ilegal, menos aún podría castigársele penalmente por cometer faltas administrativas en su ingreso. Pero esta prohibición va dirigida a la conducta del migrante y no a la del traficante, como es la descripción penal del tráfico.

En el tráfico ilícito de migrantes, se sanciona al tercero que lucra con la actividad de promover o facilitar los ingresos ilegales de migrantes, y una interpretación restrictiva del ingreso ilegal solo deja a salvo las hipótesis creativas de los traficantes para lograr sus objetivos y no protege en ningún caso al migrante. Aquí, se puede caer en una cierta «trampa del buenismo» en la que, creyendo que se protege al migrante, finalmente, al no comprender hipótesis amplias de ingreso ilegal, se termina protegiendo al traficante hábil. 
La interpretación restrictiva, basada en la protección de los derechos de los migrantes, yerra al sostener que una persona que ingresa como turista y que viene a trabajar, al tener la posibilidad de mutar su estatus migratorio, está en una situación migratoria regular.

Ese migrante tiene una expectativa de mutar la calidad migratoria de turista a trabajador, pero si no lo logra y vence el plazo de la visa de turista, queda en una situación de vulnerabilidad que hasta podría ser víctima de otros delitos, como la trata de personas. Una vez que el plazo venció y no ha podido mutar su estatus, cae en una situación migratoria irregular y la conducta del sujeto activo que promovió o facilitó ese ingreso, según esta visión, sería atípica.

Para concluir, la ambigüedad del bien jurídico en este delito producto de rechazar la posibilidad de que en la figura básica lo protegido sea el sistema migratorio y de buscar alguna justificación más aceptable penalmente que este bien colectivo, ha dado lugar a interpretaciones disímiles del contenido del elemento ingreso ilegal, lo que puede perpetuarse mientras no se zanje esta discusión. Mientras tanto, los traficantes de migrantes pueden resultar impunes en situaciones de ingresos ilegales a las que se les dé una interpretación restrictiva bajo la fantasía de estar protegiendo a los migrantes.

\section{Excurso: Entrada ilegal en el proyecto de Ley de Migraciones}

En el contexto nacional, en el que reactivó la discusión de la Ley de Migraciones (Boletín 8970-06) que sustituirá al Decreto Ley de Extranjería de la década del setenta, actualmente se está debatiendo si las puertas del país estarán abiertas a la migración o movilidad humana, cerradas o semicerradas, y de estas definiciones dependerá la configuración de elemento normativo entrada ilegal una vez que entre en vigor la nueva ley (Sandoval, 2018: 33).

El proyecto de ley, entre otras materias, indica los requisitos de ingreso al país para los extranjeros o no residentes. Para esto, señala prohibiciones facultativas e imperativas de entrada, estrechamente relacionadas con la configuración del ingreso ilegal.

Entre las prohibiciones imperativas señala:

Artículo 32.- Prohibiciones imperativas. Se prohíbe el ingreso al país a los extranjeros que: 8 . No cumplan los requisitos de ingreso establecidos en esta ley y su reglamento y en los decretos respectivos que fijan las categorías migratorias. ${ }^{39}$

Con este numeral, se cumple lo comprometido por Chile con la suscripción, ratificación y vigencia de la Convención de Palermo y el protocolo contra el tráfico ilícito

39. Para más información, véase el Boletín 8970-o6, disponible en bit.ly/366URzA. 
de migrantes, en cuanto a que el ingreso ilegal se configura al no cumplir con los requisitos de ingreso al país, ya que el no cumplirlos es una prohibición imperativa de ingreso.

Pero, luego, en las prohibiciones facultativas, señala:

Artículo 33.- Prohibiciones facultativas. Podrá impedirse el ingreso al territorio nacional a los extranjeros que: 4 . Realicen declaraciones manifiestamente falsas al momento de obtener la visa o presentarse ante el control migratorio.

$\mathrm{Al}$ establecer como impedimento facultativo el ingreso con declaraciones falsas e incluso la ejecución de actos o de porte de elementos que generan sospecha de una finalidad distinta de la manifestada, ya sea para obtener la visa o al presentarse al control migratorio, esta causal queda fuera de los impedimentos imperativos, y se establece aparte como una situación distinta del incumplimiento de los requisitos de ingreso establecidos en la ley.

Esto podría generar nuevamente lecturas distintas en cuanto a la interpretación del elemento normativo ingreso ilegal. Esto porque, al tratarse las declaraciones falsas para entrar o salir y para obtener visas, como prohibición facultativa, generará dudas razonables acerca de si constituyen o no ingresos ilegales.

Pero, por otro lado, en las prohibiciones imperativas se señala, en forma genérica, que se prohíbe el ingreso de los extranjeros que no cumplan con las normas de esta ley y de su reglamento, con lo que no se entendería si las declaraciones verdaderas forman o no parte de los requisitos de entrada al país.

De mantenerse la redacción planteada, si una persona obtiene la visa de trabajo para venir a Chile con declaraciones falsas o si declara una finalidad falsa al funcionario contralor, podría interpretarse que ingresa de manera legal, ya que sería facultativo no dejarla ingresar, a diferencia de quienes genéricamente no cumplen con los requisitos de ingreso, para quienes la prohibición es imperativa cuando la declaración falsa es justamente constitutiva de un incumplimiento de los requisitos de ingreso.

La separación entre el incumplimiento general de requisitos de ingreso, de las declaraciones falsas, en circunstancia de que entre ellas hay relación de género a especie, no simplifica el entendimiento de qué es la entrada ilegal, elemento normativo del tipo de tráfico ilícito de migrantes.

El proyecto de Ley de Migración, en su redacción actual, está lejos de resolver las dudas acerca de qué configura la entrada ilegal en Chile, por lo que presumiblemente esta ley y las distintas visiones del bien jurídico protegido seguirán alimentando interpretaciones diversas del elemento normativo de este tipo penal. 


\section{Referencias}

Arroyo, Luis (1997). Comentarios al Código Penal. Madrid: Iustel.

AviLÉs, Cassandra (2017). «El tráfico ilícito de migrantes en Chile». Justica do Direito, 31 (2): 229-245. Disponible en bit.ly/34Ypd5i.

BASCuÑán, Antonio (2017). «El delito de tráfico ilícito de migrantes. Presentación en las III Jornadas de Derecho Penal del Norte en la ciudad de Arica». Disponible bit.ly/3nnmfQ1.

Cancio, Manuel y Mario Maraver (2006). «El derecho penal español ante la inmigración: un estudio político criminal». Revista Cenipec, 25 (2): 33-121. Disponible en bit.ly/2TopFup.

CÁrdenas, Claudia (2011). «El delito de tráfico de migrantes con especial referencia a la legislación chilena». En Universidad de Valparaíso, Facultad de Derecho y Ciencias Sociales (compilador), Actas del Congreso Internacional de Derecho: en homenaje al Centenario de la Escuela de Derecho de la Universidad de Valparaíso (pp. 435-466). Valparaíso: Universidad de Valparaíso.

DiAs, Guilherme (2017). «Trata de personas, tráfico de migrantes y la gobernabilidad de la migración a través del crimen». Etnográfica, 21 (3): 541-554. Disponible en bit.ly/355VoQr.

DUARTE, Thamara (2015). Inmigración, tratamiento jurídico penal en el derecho español. Juruá: Porto.

Durán, Mario (2019). «Propuestas para la delimitación típica e interpretación sistemática del nuevo delito de tortura y su bien jurídico protegido». Política Criminal, 14 (27): 202-241. Disponible en bit.ly/361MkxV.

GajARDo, Tania y Angélica Torres (2011). «Los tipos penales de tráfico de migrantes y trata de personas en la Ley 20.507». Revista Jurídica del Ministerio Público, 47: 231-251. Disponible en bit.ly/385zmih.

Maldonado, Francisco (2012). «Acceso a la justicia». En Seminario Internacional sobre trata de personas y tráfico de migrantes (pp. 99-104) Santiago: Maval.

Mardones, Fernando y José Fernández José (2011). «Ley 20.507, tipifica el tráfico de inmigrantes y trata de personas». En Departamento de estudios Defensoría Nacional, 5 .

Martínez, Margarita (2007). La inmigración como delito. Un análisis político criminal, dogmático y constitucional del tipo básico del artículo 318 bis. Barcelona: Atelier.

Matus, Jean Pierre y María Cecilia Ramírez (2014). Lecciones de derecho penal chileno. 3. ${ }^{\mathrm{a}}$ ed. Santiago: Legal Publishing.

Moya, Clara (2016). «Los delitos de trata de seres humanos en España y Chile. Bien jurídico protegido y relaciones concursales». Revista Política Criminal, 11, (22): 521-547. Disponible en bit.ly/3lgcbZ6. 
Muñoz Conde, Francisco (2004). Derecho penal: Parte especial. Valencia: Tirant Lo Blanch.

PÉrez, Esteban (2008). Tráfico de personas e inmigración clandestina. Valencia: Tirant Lo Blanch.

PÉrez, Ana (2004). Globalización, tráfico internacional ilícito de personas y derecho penal. Granada. Comares.

Pomares, Esther (2015). «Reforma del código penal español en torno al delito de tráfico ilegal de migrantes como instrumento de lucha contra La inmigración ilegal en la Unión Europea». Revista de Estudios Jurídicos UNESP, 19 (29): 1-20. Disponible en bit.ly/3miBaic.

Rodríguez, María José (2001). Delitos contra los derechos de los ciudadanos extranjeros. Valencia: Tirant Lo Blanch.

Salinero (2019). Casos destacados derecho penal. Parte especial. Santiago: DER.

SAndoval, Rodrigo (2018). «La migración en el Chile de hoy». En Pablo Arellano (editor), Migración y trabajo. Miradas desde el derecho nacional e internacional (pp. 27-64). Santiago: Librotecnia

Segovia, Antonio (2013). "Algunas consideraciones sobre el delito de tráfico ilícito de migrantes». Revista Jurídica del Ministerio Público, 56: 215-239. Disponible en bit.ly/39bMJ2X.

Serrano-Piedecasas, José (2002). «Los delitos contra los derechos de los ciudadanos extranjeros». En Patricia Laurenzo (coordinadora), Inmigración y derecho penal. Bases para un debate. Valencia: Tirant Lo Blanch.

SPEnER, David (2008). «El apartheid global, el coyotaje y el discurso de la migración clandestina: Distinciones entre violencia personal, estructural y cultural». Migración y desarrollo, 10: 127-156. Disponible en bit.ly/3631i6F.

Villacampa, Carolina (2011). «Título VII bis». En Gonzalo Quintero (director), Comentarios a la parte especial del derecho penal (pp. 265-303). Pamplona: Aranzadi.

\section{Sobre la autora}

Tania Alejandra Gajardo Orellana es abogada y licenciada en Derecho por Universidad de Chile. Además, es magíster en Derecho por la Universidad de Navarra y candidata a doctora en Derecho por la Universidad de los Andes. Su correo electrónico es tgajardoorellana@gmail.com. (D) https://orcid.org/ooo o-0001-9853-7911. 
La Revista de Estudios de la Justicia es publicada, desde 2002, dos veces al año por el Centro de Estudios de la Justicia de la Facultad de Derecho de la Universidad de Chile. Su propósito es contribuir a enriquecer el debate jurídico en el plano teórico y empírico, poniendo a disposición de la comunidad científica el trabajo desarrollado tanto por los académicos de nuestra Facultad como de otras casas de estudio nacionales y extranjeras.

\author{
DIRECTOR \\ Álvaro Castro \\ (acastro@derecho.uchile.cl) \\ SITIO WEB \\ rej.uchile.cl \\ CORREO ELECTRÓNICO \\ cej@derecho.uchile.cl \\ LICENCIA DE ESTE ARTÍCULO \\ Creative Commons Atribución Compartir Igual 4.o Internacional
}

La edición de textos, el diseño editorial y la conversión a formatos electrónicos de este artículo estuvieron a cargo de Tipográfica

(www.tipografica.io) 